\title{
Comparative Microbiological Assessment of Drinking Water Collected from Different Areas of Kathmandu Valley
}

\author{
Aman Thapa Magar ${ }^{1}$, Mamata Khakurel ${ }^{1}$, Shree Laxmi Pandey ${ }^{1}$, Kalyan Subedi ${ }^{1}$, Umesh Kaji \\ Manandhar ${ }^{1}$, Swechhya Karanjit ${ }^{1}$ Rabin Paudyal ${ }^{1}$ \\ ${ }^{1}$ Department of Microbiology, Kathmandu College of Science and Technology, Kamalpokhari, Kathmandu
}

*Corresponding author: Rabin Paudyal, Department of Microbiology, Kathmandu College of Science and Technology, Kamalpokhari, Kathmandu; Email: rpaudyal@kist.edu.np

\section{ABSTRACT}

Objectives: This study was aimed to evaluate different water samples in terms of total bacterial load and total coliform load in comparison with different parameters such as $\mathrm{pH}$, type of samples, chlorination status, turbidity, temperature and collection areas.

Methods: Altogether 250 water samples were collected; 110(44\%) were ground water samples, $60(24 \%)$ were public tap water samples and $80(32 \%)$ were bottled water samples. Total Coliform load was evaluated using Membrane Filtration Technique and Total Bacterial Load was evaluated using Aerobic Plate Count Technique. $\mathrm{pH}$ was measured using $\mathrm{pH}$ meter, turbidity was measured using nephelometer, temperature was measured using temperature probe and bottled water were considered chlorinated.

Results: Among these 250 samples, the highest mean bacterial load was seen in public tap water samples $\left(137 \times 10^{3} \mathrm{cfu} / \mathrm{ml}\right)$ and least mean bacterial load was seen on bottled water sample $\left(28 \times 10^{3}\right)$. Similarly, highest mean coliform load was seen on ground water samples $(81 \mathrm{cfu} / \mathrm{ml})$ and least mean coliform load was seen on bottled water samples $(6 \mathrm{cfu} / \mathrm{ml})$.

Conclusion: This study has concluded that ground water samples contain large number of coliforms which suggest it might be fecally contaminated. Also the result had shown even bottled water contained coliforms. Therefore, it is recommended to treat ground water before using. Proper care must be taken during manufacture of bottled water.

Key words: Water samples, total bacterial load, total coliform load.

\section{INTRODUCTION}

Water covers $70 \%$ of the earth surface and is also present in varying amount in the atmosphere. It is an essential component of all cells and a requirement for life. Consequently, 250 million people are exposed to waterborne disease resulting in 10-20 million deaths every year (Pironcheva 2004). It is well known that $88 \%$ of the global diarrheal diseases are water-borne infections caused by drinking unsafe and dirty water (Gundry et al. 2004). Nepal faces a serious crisis of potable drinking water in both urban cities and rural areas.

In Nepal, every summer, water borne epidemics (of diarrhea, cholera, typhoid, etc.) hit different parts of the country including Kathmandu valley and cause a heavy

Date of Submission: September 5, 2019

Published Online: December, 2019 death toll. Most of the water sources in Kathmandu valley do not comply with the guidelines provided by WHO (Bottino 1991).

This study was conducted with an objective to assess the microbiological quality of water in terms of heterotrophic bacteriological load and coliform load. This research would contribute to evaluate the safety of drinking water and provide information on further treatment necessary for drinking water. The results of this research can be an open source for academic and be put to scrutiny for any and all.

\section{MATERIALS AND METHODS}

The study was conducted on water sample collected

Date of Acceptance: November 22, 2019

DOI: https:/ / doi.org/10.3126/tujm.v6i0.26577 
from different places of Kathmandu valley. The study was conducted in Microbiology Laboratory of Kathmandu College of Science \& Technology, Kamalpokhari, Kathmandu, Nepal. The water samples were collected in pre-sterilized glass BOD bottles (15lbs at $121^{\circ} \mathrm{C}$ for 15 minutes) of $300 \mathrm{ml}$ capacity and transported in an ice box containing freezer ice packs. These samples were processed as soon as arrival in the laboratory. $\mathrm{pH}$ was measured on site by using automatic digital $\mathrm{pH}$ meter (Hanna instruments) and temperature by dipping bulb of standard temperature probe (Hanna instruments). Turbidity was determined by using nephelometer (Hanna instruments). Jar water and bottled water sample was considered chlorinated. A total of $100 \mathrm{ml}$ each water sample was filtered through
$0.45 \mu \mathrm{m}$ membrane filter (Pall Corporation). The membrane filter was aseptically transferred to Eosin Methylene Blue agar (EMB, HiMedia Laboratories) and incubated at $37^{\circ} \mathrm{C}$ for $24 \mathrm{hrs}$. Coliforms were enumerated by observing pink colonies with or without metallic sheen grown in EMB agar. Bacterial load was determined using plate count agar (PCA) technique. Enumeration was done after incubation at required temperature and time. Comparative distribution of bacterial and coliform load was done with various parameters.

\section{RESULTS}

A total of 250 samples were collected from various sources such as ground $110(44 \%)$, public tap water $60(24 \%)$ and bottled water $80(32 \%)$ as shown in fig.1

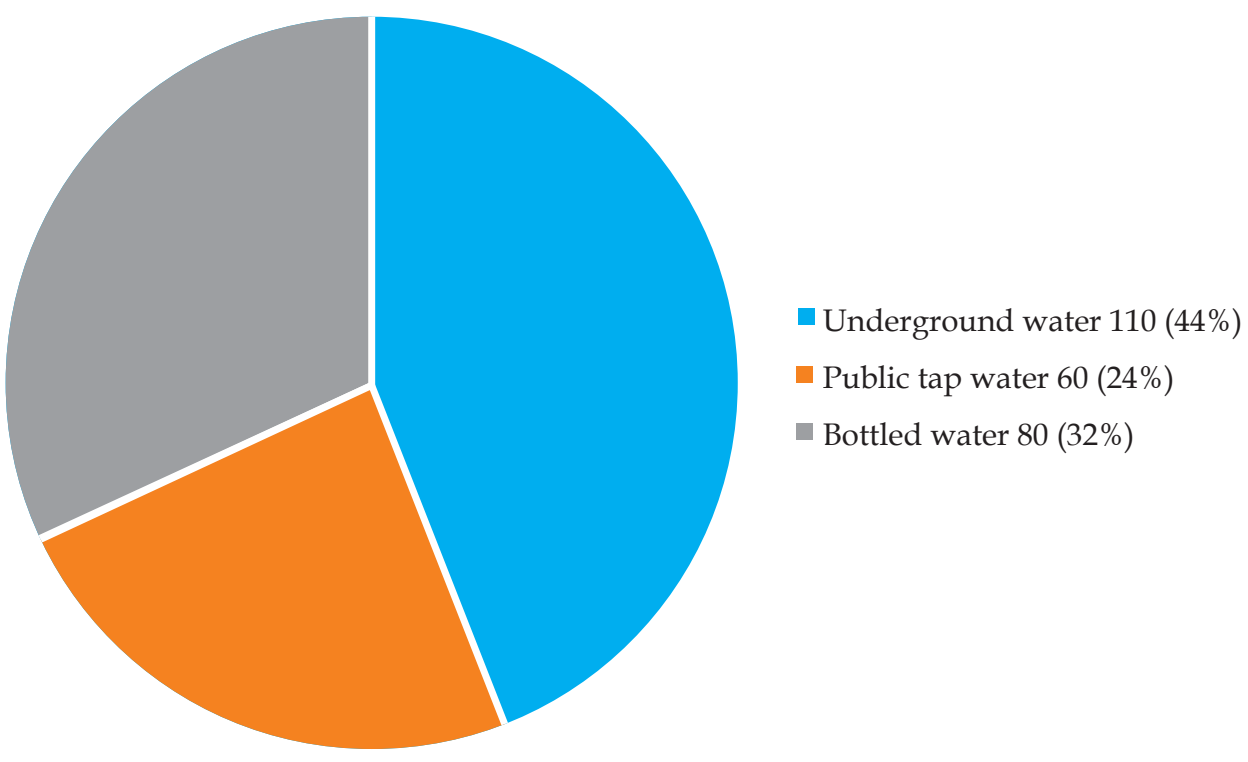

Figure 1. Distribution of water from various sources

These collected samples were designated as Area 1, Area 2, Area 3 \& Area 4. Area 1 consist of places such as Kamalpokhari, Kamaladi, Teku, Tripureshwor, Kirtipur, Dhobidhara, Bagbajar, Dillibajar, Nagpokhari, Gairidhara and Panipokhari. Area 2 - Kapan, Bafal,
Sundarijal, Boudha, Bansbari, Baluwatar, Balaju. Area 3- Kuleshwor, Anamnagar, Sitapaila, Patan, Sanepa, Bhaktapur. Area 4 - Tahachal. These area wise distribution of water samples are shown in fig 2. 


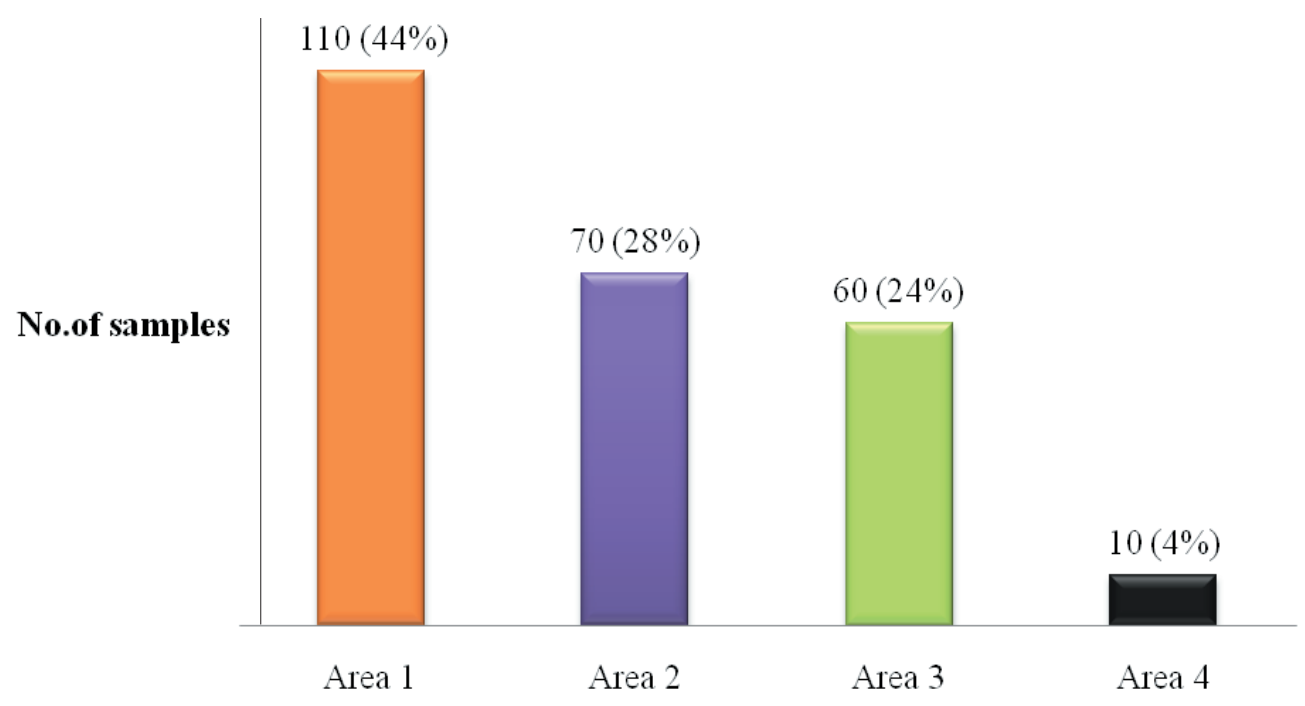

Figure 2. Area wise distribution of water samples

The highest bacterial load was observed on public tap water $\left(137 \times 10^{3}\right) \mathrm{cfu} / \mathrm{ml}$ and least bacterial load was observed on bottled water samples $\left(28 \times 10^{3}\right) \mathrm{cfu} / \mathrm{ml}$ as shown in table 1.

Table 1: Distribution of bacterial load in different water samples.

\begin{tabular}{lcc}
\hline Type of samples & Total no. of samples & Mean bacterial load (cfu/ml) \\
\hline Ground water & 110 & $130 \times 10^{3}$ \\
Public tap water & 60 & $137 \times 10^{3}$ \\
Bottled water & 80 & $28 \times 10^{3}$ \\
\hline
\end{tabular}

The highest mean coliform load was seen on ground

load was seen on bottled water samples $(6 \mathrm{cfu} / 100 \mathrm{ml})$ water samples $(81 \mathrm{cfu} / 100 \mathrm{ml})$ and least mean coliform (Table 2).

Table 2: Distribution of coliform load in different water samples.

\begin{tabular}{lcc}
\hline Type of samples & Total no. of samples & Mean coliform load (cfu/ 100ml) \\
\hline Ground water & 110 & 81 \\
Public tap water & 60 & 30 \\
Bottled water & 80 & 6 \\
\hline
\end{tabular}

The highest mean coliform load with respect to different Areas was observed on area 2 (55cfu/100ml) \& least mean coliform load was seen on Area 4 (3 cfu/100ml) (table 3).

Table 3: Distribution of coliforms in water samples of different areas.

\begin{tabular}{lcc}
\hline Area & Total no. of samples & Mean coliform load (cfu/100ml) \\
\hline Area 1 & 110 & 45 \\
Area 2 & 70 & 55 \\
Area 3 & 60 & 32 \\
Area 4 & 10 & 3 \\
\hline
\end{tabular}

The highest bacterial and coliform load with respect to different temperature range was observed on temperature range $\left(26^{\circ} \mathrm{C}\right.$ to $\left.27^{\circ} \mathrm{C}\right)$ i.e. $123 \times 10^{3} \mathrm{cfu} / \mathrm{ml}$ and
$61 \mathrm{cfu} / 100 \mathrm{ml}$ respectively while the least bacterial and coliform load was observed in temperature range $\left(24^{\circ} \mathrm{C}\right.$ to $25^{\circ} \mathrm{C}$ ) i.e. $41 \times 10^{3} \mathrm{cfu} / \mathrm{ml}$ and $4 \mathrm{cfu} / 100 \mathrm{ml}$ (Table4). 
Table 4: Distribution of bacterial and coliform load in water samples in different temperature range

\begin{tabular}{lccc}
\hline Temperature & Total No. of sample & Mean bacterial load $(\mathrm{cfu} / \mathrm{ml})$ & Mean coliform load $(\mathrm{cfu} / 100 \mathrm{ml})$ \\
\hline $24-25^{\circ} \mathrm{C}$ & 10 & $41 \times 10^{3}$ & 4 \\
$25-26^{\circ} \mathrm{C}$ & 50 & $71 \times 10^{3}$ & 6 \\
$26-27^{\circ} \mathrm{C}$ & 60 & $123 \times 10^{3}$ & 61 \\
$27-28^{\circ} \mathrm{C}$ & 130 & $89 \times 10^{3}$ & 56 \\
\hline
\end{tabular}

The highest mean bacterial and coliform load in different water samples with respect to turbidity was observed on turbid water $\left(85 \times 10^{3} \mathrm{cfu} / \mathrm{ml}\right.$ and 74

$\mathrm{cfu} / 100 \mathrm{ml}$ ) while least bacterial and coliform load was observed in non-turbid water $\left(68 \times 10^{3} \mathrm{cfu} / \mathrm{ml}\right.$ and 30 cfu/100ml) (table 5)

Table 5: Distribution of bacterial and coliform load in water samples with respect to turbidity

\begin{tabular}{|c|c|c|c|}
\hline Turbidity & Total No. of samples & No. of bacterial load (cfu/ml) & No. of coliform load (cfu/100ml) \\
\hline Turbid & 70 & $85 \times 10^{3}$ & 74 \\
\hline Non-turbid & 18 & $68 \times 10^{3}$ & 30 \\
\hline
\end{tabular}

The highest mean bacterial and coliform load in different water samples with respect to water treatment was seen on non-treated water $\left(106 \times 10^{3} \mathrm{cfu} / \mathrm{ml} \& 83\right.$ $\mathrm{cfu} / 100 \mathrm{ml})$ while the least mean bacterial \& coliform load was observed in treated water $\left(28 \times 10^{3} \mathrm{cfu} / \mathrm{ml} \&\right.$ $23 \mathrm{cfu} / 100 \mathrm{ml}$ ) (table 6).

Table 6: Distribution of bacterial and coliform load in water samples with respect to water treatment.

\begin{tabular}{lccc}
\hline Chlorination & Total No. of samples & Total bacterial load (cfu/ml) & Total coliform load (cfu/100ml) \\
\hline Chlorinated & 80 & $28 \times 10^{3}$ & 23 \\
Non-chlorinated & 170 & $106 \times 10^{3}$ & 83 \\
\hline
\end{tabular}

The highest mean bacterial and coliform load in different water samples with respect to $\mathrm{pH}$ range was seen between 5-6 \& 6-7 $\left(94 \times 10^{3} \mathrm{cfu} / \mathrm{ml}\right.$ and 50 $\mathrm{cfu} / 100 \mathrm{ml}$ ) while the least mean bacterial \& coliform load was observed in $\mathrm{pH}$ range between 6-7 and 5-6 $\left(67 \times 10^{3} \mathrm{cfu} / \mathrm{ml}\right.$ and $\left.46 \mathrm{cfu} / 100 \mathrm{ml}\right)$ (table 7$)$.

Table 7: Distribution of bacterial and coliform load in water samples with respect to $\mathrm{pH}$

\begin{tabular}{cccc}
\hline $\mathrm{pH}$ & Total No. of sample & Mean bacterial load $(\mathrm{cfu} / \mathrm{ml})$ & Mean coliform load $(\mathrm{cfu} / 100 \mathrm{ml})$ \\
\hline $5-6$ & 130 & $94 \times 10^{3}$ & 46 \\
$6-7$ & 120 & $67 \times 10^{3}$ & 50 \\
\hline
\end{tabular}

\section{DISCUSSION}

This study assesses the physiochemical and microbiological quality of bottled water, ground water and public tap water collected around different areas of Kathmandu valley. The highest number of sample was underground water (110) followed by bottled water (80) and public tap water (60).

The result was found to be consistent with various other studies conducted, which found $82.6 \%$ and $92.4 \%$, drinking water samples were not consistent with the WHO guideline of drinking water (Prasai 2007). In similar study, total coliform positive rate of $80 \%$ was reported for mineral or euroguard treated water (Rai et al. 2012). In present study, it showed ground water samples contain highest bacterial \& coliform loads. Similar study done in Kathmandu valley, Nepal enumerated $267 \mathrm{cfu} / \mathrm{ml}$ coliform load in ground water samples (Pant 2011). Following ground water, mean coliform load was high in public tap water i.e. $30 \mathrm{cfu} / 100 \mathrm{ml}$. A similar study found $91.18 \%$ of contamination by coliforms (Aryal et al. 2012). This may be due to contamination in pipeline system, drainage system and discontinuity in water supply pattern or carelessness. Contamination in bottles may be due to improper handling, improper disinfections, infiltration of contaminated water, leakage etc.

On evaluating data of distribution of coliform in water samples of different areas, Area 2 showed highest number of coliform distribution. This may be due to the fact that most of the samples from area 2 were ground water samples. Similarly, coliform distribution was higher in turbid water sample and temperature range of $27^{\circ} \mathrm{C}$ to $28^{\circ} \mathrm{C}$. In this study, the highest distribution of coliform was observed at $\mathrm{pH}$ 6-7. This may be due to fact that most of coliforms are neutrophillic and optimally grow in neutral $\mathrm{pH}$.

\section{CONCLUSION}

This study concludes that ground water, public water and even bottled water consist of high bacterial load 
\& coliform contamination. Ground water was found to be unsafe for drinking purpose as it contained highest coliform contamination. Bottled water was seen much safer than ground and public tap water as it contained comparatively less bacterial load and coliform contamination. Ground water must be treated properly before using for drinking purpose. Public tap water must be properly disinfected before using and bottled water must be monitored properly during manufacturing.

\section{ACKNOWLEDGEMENTS}

The authors are very thankful to Kathmandu College of Science and Technology (KCST), Kamalpokhari, Kathmandu for providing necessary laboratory arrangement for the successful completion of the study.

\section{CONFLICT OF INTEREST}

The author declares no conflict of interest.

\section{REFERENCES}

Aryal J, Gautam B and Sapkota N (2012). Drinking Water quality assessment. J Nepal Health Res Council 10(22): 192-196.

Bottino A, Thapa A, Scatoline A, Ferino B, Sharma S and Pradhananga MT (1991). Pollution in Water Supply System of Kathmandu City. Journal of Nepal Chemical Society 10: 33-44.

Gundry S, Wright J and Conroy R. (2004). A systematic review of the health outcomes related to household water quality in developing countries. J Water Health 2: 1-13.

Pant BR (2011). Ground water quality in the Kathmandu Valley of Nepal, Environmental Monitoring and Assessment 178 (1-4): 477-85

Pironcheva (2004). Water Management Practises in Rural and Urban Homes; a case of of Bangladesh on Ingestion of Polluted water. J. Public Health 112: $317-321$.

Prasai T, Lekhak B, Joshi DR and Baral MP (2007). Microbiological Analysis of Drinking Water of Kathmandu Valley. Scientific World 5(5): 112-114.

Rai SK, Ono K, Yanagida J-I, Ishiyama- Imura Kurokawa M and Rai CK (2012). A large-scale study of bacterial contamination of drinking water and its public health impact in Nepal. Nepal Med Coll J 14(3): 234-240. 